\title{
Academic Libraries in Greece: a New Perspective
}

\author{
Paschalis Raptis and Anestis Sitas
}

Published in: Libri, vol. 46, no. 2 (June 1996), pp. 100-112

\begin{abstract}
The current status of the academic libraries in Greece is examined. A brief summary of each academic institution and its library is given. Collection development, staff, and the bibliographic organization of the materials are described. The bib-

\section{Introduction}

Panepistimia (universities), polytechnia (schools of engineering) and Anotates Scholes (higher schools) are the academic institutions in Greece. The schools of engineering are either autonomous or belong to a university. There are a total of eighteen public academic autonomous institutions in Greece. On the other hand Technological Educational Institutions (TEI) are three and a half year technical colleges.

In 1984 Dr. Krikelas published a paper that was the first serious appraisal of the problem areas that Greek academic libraries were facing. The problem areas were: collection development, bibliographic organization, and personnel (1). Fouryears later, in a paper by Birk and Karageorgiou, the status of nine academic libraries was given as well as the legislation that concerned academic libraries (2). A report of Greek academic libraries was written in 1991 by Zachos and Papaioannou (3). The report included recommendations to make the academic libraries function better. In 1992, Dean Keller as editor published a collection of essays for the Greek academic libraries (4).

Did the academic libraries find solutions to their problems? What has changed in the last 10 years? This paper provides a description of all academic institutions and their libraries. The current status

liographic standards that libraries apply, automation and retrospective conversion are presented. General assessments, short presentation of automation systems and areas for development are also provided.

of collection development, personnel, bibliographic organization and automation is examined. The paper serves as an update of the older papers about the status of academic libraries in Greece.

\section{Data collection}

The data for this paper were collected using a variety of methods: by personal contact during the Third Meeting of the Academic Librarians in Thrace, 9-11 November 1994, with a questionnaire that was sent to 50 academic libraries and with telephone interviews for the libraries of University of Ionio. For the Aristotle University of Thessaloniki the personal experience of the two writers brings in an additional perspective.

\section{The academic institutions and their libraries}

The National Kapodistrian University of Athens (N.K.U. Athens) was founded in 1837 and was called Othoneio University. In 1862 it was renamed National University and finally obtained its current name. The University consists of nine schools, and 24 departments with 45,000 students. The old campus is still in the center of Athens but there are many buildings dispersed all over the city (fifteen different locations). The libraries are isolated and work independently from each other. There are about 40 departmental and/or sectional libraries.
\end{abstract}


Even though it was the first (5) university founded in Greece, the status of its library system is rather chaotic. There is no coordination nor a union catalog of the collection. There are small unorganized collections that can hardly be considered libraries. Some of these have rather large collections. Every library processes its own material and follows different standards in bibliographic organization. As a result some libraries are well organized, others not. Here are some indicative data for libraries that answered the questionnaire:

The sectional library of the Classical Studies Department has 50,000 volumes and 350 serial titles. It follows Anglo-American Cataloguing Rules Rev.2 (AACR2), it has its own developed classification system, and the subject headings are not based on any of the standard headings. The card catalog provides author, title and subject access.

The sectional library of the Byzantine \& Modern Greek Philology follows AACR2, Dewey Decimal Classification (DDC), and Library of Congress Subject Headings (LCSH). It holds 22,000 volumes and 500 journals. The card catalog provides the three traditional access points (author, title, subject).

The sectional library of Private Law (Labour Law \& Social Insurance) of the Law School was founded in 1982 and has 3,500 titles and 50 journals. It follows AACR2, Universal Decimal Classification (UDC), and no specific thesaurus for subject headings. It is automated with the ABEKT system (a short description of the integrated library information systems (ILIS) used in Greek academic institutions is given in APPENDIX) and uses UNIMARC format.

The sectional library of Private Law (Trade \& Nautical Law) has 12,500 volumes and 120 serial titles. It follows AACR2, UDC, and no specific thesaurus for subject headings. It is automated with the ABEKT system and uses UNIMARC format.

The sectional library of the Primary Education Department was founded in 1990. The department has been in function since 1986 and has 2,000 students. The library follows AACR2, DDC, and no specific thesaurus for subject headings. The ABEKT system is used for automation of library functions.

The library of the Physical Education Department ( 4,000 students) has 12,000 volumes, 180 serial titles and a collection of 7,000 dissertations. It follows AACR2, DDC but no specific thesaurus for subject headings. It is automated with the ANALOGIO system and uses UNIMARC format. It cooperates with physical education libraries in four universities (6) of Greece for document delivery. It seems to be one of the most organized and active libraries in the university.

The library of the School of Dentistry was founded in 1978. It has 2,000 volumes and 175 serial titles. It follows AACR2, National Library of Medicine (NLM) classification schemes and Medicine Subject Headings (MeSH). They maintain only a subject card catalog. The library uses the ABEKT system.

In addition to the old, some newly established departments make an effort to create libraries. The department of Nursing is one of those. In the beginning the department belonged in the School of Medicine (7). Since 1993, the department has been autonomous. It consists of four sections that are located in different buildings and has 240 students.

There is a building where a medical library will be created for all departments of the Medical School.

The Higher School of Fine Arts (8) (H. S. Fine Arts) was founded in 1837. Since 1930, it had been an autonomous university. It is housed in six buildings in Athens. The main building is located in the center of the city and there are five additional locations with specialized laboratories. It also has six art stations in Delphi, Mithimna of Lesbos, Mykonos, Rethymno, Rhodes and Hydra. The school has 466 students and one library that is housed in the main building with 19,000 volumes and 74 serial titles. The library uses the UDC classification schemes and maintains author and subject card catalogs.

The National Metsovian School of Engineering (N.Metsov. S.Eng) has 10,000 students in nine departments. It is located in two campuses in the city of Athens and was founded in 1914. There are two main libraries (one on each campus). Books are also found in an unknown number of locations in departmental or in sectional libraries or in the faculty's offices. The card catalogs are maintained in two copies, one in each library. The two libraries have 400 serial titles. Another 800 serial titles are dispersed in different locations on the campuses. It follows its own developed version of AACR2 and DDC. The library has just bought an ILIS called ALEF and it has a mini computer, an Ether- 
Table 1. Academic institutions by date of founding.

\begin{tabular}{|c|c|c|c|c|}
\hline Institution & Found & Students & Volumes & Serial Titles \\
\hline \multicolumn{2}{|l|}{ N. K. U. Athens: } & 45,000 & $\mathrm{~N} / \mathrm{A}$ & $\mathrm{N} / \mathrm{A}$ \\
\hline \multicolumn{2}{|l|}{ Classic } & N/A & 50,000 & 350 \\
\hline \multicolumn{2}{|l|}{ Byzantine } & $\mathrm{N} / \mathrm{A}$ & 22,000 & 500 \\
\hline \multicolumn{2}{|l|}{ Priv. Law } & N/A & 3,500 & 50 \\
\hline \multicolumn{2}{|l|}{ Trade Law } & N/A & 12,500 & 120 \\
\hline \multicolumn{2}{|l|}{ Phys. Ed. } & 4,000 & 12,000 & 180 \\
\hline \multicolumn{2}{|l|}{ Dentistry } & $\mathrm{N} / \mathrm{A}$ & 2,000 & 175 \\
\hline H.S. Fine Arts & 1837 & 466 & 19,000 & 74 \\
\hline N. Metsov. S. Eng & 1914 & 10,000 & 80,000 & 400 \\
\hline A. U. Econ \& Bus. & 1920 & 7,000 & 60,000 & 700 \\
\hline Agr. U. Athens & 1920 & 3,500 & 11,000 & 410 \\
\hline A.U. Thes/niki & 1925 & 50,000 & $1,600,000$ & 3,500 \\
\hline Panteio U. & 1930 & 10,000 & 60,000 & 550 \\
\hline U. Pireas & 1958 & 12,000 & 40,000 & 300 \\
\hline U. Macedonia & 1957 & 8,500 & 60,000 & 600 \\
\hline U. Ioannina & 1964 & 7,000 & 160,000 & 2,300 \\
\hline U. Patra & 1964 & 14,000 & 14,000 & 1,500 \\
\hline \multicolumn{5}{|l|}{ D. U. Thrace: } \\
\hline \multicolumn{5}{|l|}{ Komotini: } \\
\hline \multicolumn{2}{|l|}{ Law } & 2,500 & 75,000 & 460 \\
\hline \multicolumn{2}{|l|}{ Phys Ed } & 1,000 & 9,000 & 300 \\
\hline \multicolumn{2}{|l|}{ Hist } & 200 & 7,000 & 150 \\
\hline \multicolumn{5}{|l|}{ Alexandroup: } \\
\hline \multicolumn{2}{|l|}{ Medicine } & $\mathrm{N} / \mathrm{A}$ & 1,500 & 530 \\
\hline Education & & $\mathrm{N} / \mathrm{A}$ & 1,600 & 170 \\
\hline \multicolumn{2}{|l|}{ U. Crete: } & & & \\
\hline \multirow{2}{*}{\multicolumn{2}{|c|}{$\begin{array}{l}\text { Herakleio } \\
\text { Rethymno }\end{array}$}} & 2,000 & 60,000 & 250 \\
\hline & & 2,500 & 190,000 & 700 \\
\hline S. Eng. Crete & 1977 & 800 & 23,000 & 600 \\
\hline \multicolumn{5}{|l|}{ U. Aegeo: } \\
\hline $\begin{array}{l}\text { Samos } \\
\text { Chios }\end{array}$ & 1985 & 600 & 9,000 & $\begin{array}{l}120 \\
150\end{array}$ \\
\hline Mitilini & 1986 & 900 & 6,000 & 250 \\
\hline Rhodes & $\mathrm{N} / \mathrm{A}$ & 500 & 2,000 & $\mathrm{~N} / \mathrm{A}$ \\
\hline U. Ionio & 1984 & 1,000 & 32,000 & 600 \\
\hline U. Thessalia & 1984 & $\mathrm{~N} / \mathrm{A}$ & 28,000 & 300 \\
\hline Charokopeios & 1984 & $\mathrm{~N} / \mathrm{A}$ & 4,000 & 5 \\
\hline Totals: & & 182,266 & $2,706,600$ & 17,594 \\
\hline
\end{tabular}

net Local Area Network (LAN), 10 personal computers (PCs), and one SPARC-station. The two libraries will be connected either with leased lines or through the Internet.

The Athens University of Economics and Business (A. U. Econ\&Bis) was formed in 1920 (Law 2191) as a Higher School of Commercial Studies. In 1926 its name changed to Higher School of Economics and Commercial Sciences. The school was known with the acronym ASOEE. In 1989, with the Presidential Decree 377, the name Athens University of Economics and Business was given. The university has 10,000 students in six departments: Management and Administration, Economics, In- ternational and European Financial Studies, Business Administration and Marketing, Informatics, and Statistics. The library was founded in 1935 and has 60,000 volumes and 700 serial titles. The DDC classification of the materials started in 1978. Since 1989, the library uses the ILIS EQUILIBRIUM and UNIMARC for electronic cataloguing.

The Agricultural University of Athens (Agr. U. Athens) was founded in 1920 (Act 1844, January 14). Today it has 3,500 students in seven departments. It is housed on one campus and has a central library, with about 41 departmental and sectional libraries. The central library has approximately 11,000 volumes and 80 serial titles. There 
are about 330 serial titles in the departmental and sectional libraries. The central library processes only its own materials. It has no authority over the functions of the departmental libraries. These can hardly be called "libraries" because there is no means of organization and no union catalog. The central library uses the AACR2, UDC classification system and maintains no union catalog except of a shelf list. The micro CD/ISIS is used for the automated cataloging and the online public access catalogue (OPAC). A program written in Clipper programming language is used for serial's check-in. The library has a mini computer and an integrated library information system is going to be bought. The library has access to the Internet.

The Aristotle University of Thessaloniki (A. U. Thes/niki) is the biggest and one of the oldest universities in Greece. It offers all fields of study in engineering, sciences, social sciences, arts, and humanities. In total it has seven schools and 42 departments. It was founded in 1925 and, a year later, a library was created in the building of the Philosophy School. That library served as the central library. In 1974 the collection and staff were transferred a new building, that was exclusively designed to house a library. This is an exception to the rule where no special care is given to library buildings. It has a union catalog for all the material acquired since its establishment.

The university libraries system consists of one central library, and 40 peripheral libraries. There are 50 additional locations where books are distributed. These locations can be a laboratory, a hospital clinic, an office of a faculty member, etc (in and off campus) and they cannot be considered as libraries. All the libraries together contain about 1,600,000 items. Because of the duplication of material it is estimated (9) that the unique titles are about $1,000,000$. Some 300,000 items are housed in the central library. The library system subscribes to about 3,500 serial titles. Serials are distributed to 205 different locations.

The central library sets the standards that the LS follows. The LS uses AACR2, LC classification schemes. For the non-Greek material subjects in English from LCSH are assigned. For the Greek material, subjects in Greek from Greek Subject Headings (10) are assigned. In fact only about twenty peripheral libraries cooperate with the central library. The responsibility for the lack of cooperation lies, on one hand, with the faculty members that adminis- ter the libraries and, on the other hand, with the central library that is not able to find solutions to the problems in the peripheral libraries.

The faculty members of each department decide which book titles or library materials to buy. For the serials the departments propose to the library committee what serial-title they would like to have and the central library makes the final decision depending on the availability of funds.

The university maintains (since 1984) an exchange program for librarians with Kent State University (KSU), Ohio, USA. Five librarians have been trained in KSU library. Mutually, librarians and library administators from KSU have worked in Library system offering valuable advice and expertise.

All current material of the library system is processed in the central library. It has no current collection. The serials' invoice control, check-in and claiming are done in central library.

Since 1989, the library has been a member of the OCLC (Online Computer Library Center), the biggest bibliographic utility in the world. In January 1995 the library began entering records in OCLC and receives credit for this service.

Nine employees of the central library and ten librarians that work in peripheral libraries are trained in cataloguing in MARC format. One librarian is working with bilingual authority files. In the central library, all bibliographic data for material acquired in library system from 1980 to 1991 was converted to MARC. Since 1992 all material is processed in MARC.

The central library maintains the union MARC bibliographic database, the MARC bilingual files with about 20,000 records and a card shelf list for the whole library system. A library information system (named ARIStotelis) with three modules was developed in central library: cataloguing, bilingual authority files and OPAC. The OPAC contains about 80,000 MARC records acquired from original and retrospective cataloguing. The OPAC is accessible to the university's community through the campus wide area network. The University will acquire the ILIS PTOLEMAIOS II for the automation of its libraries.

Each employee in the central library has a PC. Eight PCs offer to users access to the library's OPAC, CD-ROM databases, and to the Internet.

The peripheral libraries differ in size collection and in organization. About 20 peripheral libraries are well organized, some other 20 have an accept- 
able organization and the rest 50 cannot be considered libraries but storage locations.

One serious problem is that in some libraries the faculty members change the LC classification numbers and subject headings to different ones of their own choice. This results in inconsistencies in the LS's bibliographic database.

Peripheral libraries for Physics, English Literature, German Literature, Trade Law, and Chemistry converted their card files to MARC records using OCLC's TAPE-CON or MICRO-CON services. So a part of the card files has been converted to MARC twice, once by the central library and once by peripheral libraries. This will cause problems when the union bibliographic database is created.

Other retro projects were run by libraries for Middle-age \& Modern Greek Studies for the Greek material, and English Literature for the material acquired before 1980. Both libraries used ARIStotelis program for retro cataloguing and OPAC.

The Physics library is automated and uses the PTOLEMEOS I system.

The Aristotle University of Thessaloniki has two regional campuses, one in Florina, and one in Serres. In Florina, there is one common library for 400 students of the two education departments (primary and kindergarten). The library has 15,000 items and 100 serial titles. The PC version of ARIStotelis is used for the MARC cataloguing, and for the OPAC.

In Serres, there is only one department (physical education) which has one library.

The Panteio University of Social and Political Sciences (Panteio U.) accepted the first students in 1930 and in 1989 (Presidential Decree 377) received its current name. The university is located on one campus in the center of Athens. It has 10,000 students and fifteen departments. The library system has 60,000 items and consists of one central library and one peripheral library. All subject headings assigned, are in Greek. The library has an Ethernet network, a mini computer DEC, and 20 PCs for the staff and the users. It also has access to the Internet. All materials are processed by central library. The libraries are connected through the Ariadne network (a X.25 computer network). The GEAC Advanced system has been chosen to automate the library functions. In November 1994 the database contained 30,000 unique titles in UNIMARC. Because of the duplication, it represents the $75 \%$ of the collection.
The University of Pireas (U.Pireas) was founded in 1938 with the name "School of Industrial Studies" In 1945, it was renamed as "Higher School of Industrial Studies" and, in 1958 it was renamed again as "Highest School of Industrial Studies" The final name was given in 1989 (Presidential Decree 337 ) as University of Pireas. The university has 12,000 students in seven departments: economics, business organization \& management, statistics \& insurance, banking, technology \& production system, nautical studies, information science. Since 1993 all the departments (except nautical studies) have been housed in one building. There is one library and 4-5 small book collections with no library staff. The collection counts 40,000 items and about 300 serial titles. The library director holds a B.Sc. in Librarianship. The library has closed stacks. All card catalogs have been converted to USMARC format. The library has got a mini computer which runs the library system PTOLEMEOS II, eight IBM compatible PCs and Macintoshes for the staff and for the clients. The library seems to be one of the best organized.

The University of Macedonia of Economics and Social Studies (U.Macedonia) is located in Thessaloniki and was founded in 1948 with the name "Higher School of Industrial Studies" but really started operating in 1957-1958. That year the name changed to "Highest School of Industrial Studies of Thessaloniki" and it became a university level school. In 1966 the name changed again to "Highest Industrial School of Thessaloniki". The final name "University of Macedonia" was given in 1990. That year, the university moved into a new and modern building close to the Aristotle University. In the new building there is a specially designed place for the library. It has six departments: finance, business, international studies, accounting, information science and political science. The library has a collection of 60,000 volumes of which 30,000 are in the offices of the faculty members. The card catalog identifies the location of the material. Still, this is a negative point in the function of the library. Until 1991 the library used DDC, now LC is used. All of the collection has been re-classified with the LC schemes. Since 1993, PTOLEMEOS II has been used. The lack of personnel has resulted in only $10 \%$ of the collection being converted in MARC. The library maintains all card files. Generally it is well organized. 
Table 2. Cataloguing standards.

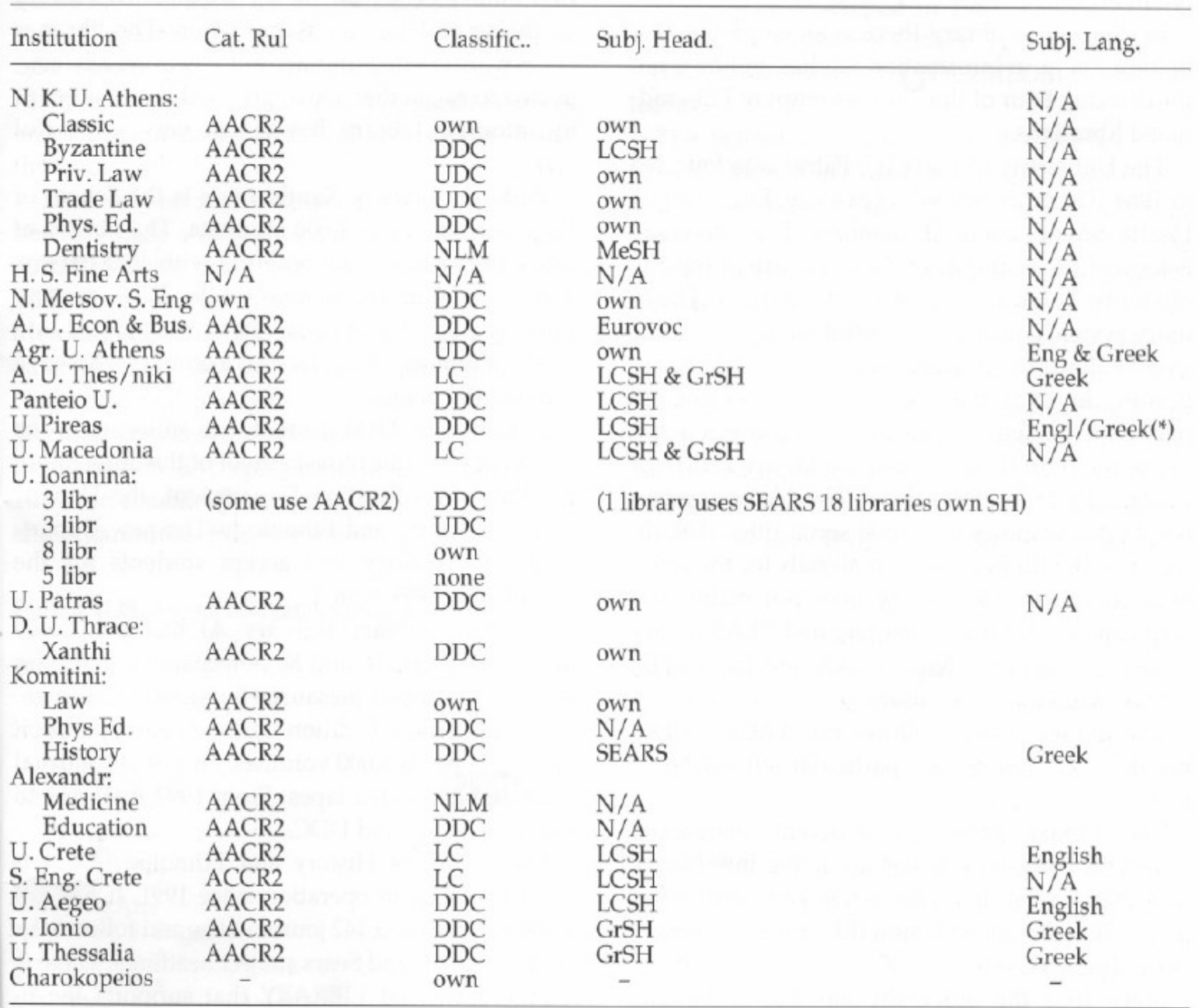

(*) The Library of U. Macedonia uses both English and Greek subject headings for the same MARC-record.

The University of Ioannina (U. Ioannina) was founded in 1964 as a regional campus for the Aristotle University of Thessaloniki. In 1970 it became an independent institution. There are three schools: sciences, philosophy, and medicine. It is housed in two campuses; one is outside the city, the other is located downtown. Soon all departments will be moved to the rural campus. Because it was a regional campus of Aristotle University it followed the same library structure. The library system has a central library and 19 departmental libraries. In addition to these libraries, there are about 20 locations (laboratories, clinics, etc) where book collections are kept. The central library loosely links the departmental libraries and is responsi- ble for the administrative procedures and for serials check-in. Until 1982 a union card catalog was kept in central library. The degree of organization differs among the libraries, some keep all the necessary files while others do not. Each library sets its own standards for the bibliographic organization. The library system has about 160,000 items, and 2,300 serial titles. Some years ago one library introduced an automation program. The project was not so successful. Fortunately all libraries now join efforts and share the PLAS system.

The current acquisitions are entered into the database. There is an attempt to complete retrospective cataloguing. By November 1994 the database held about 16,000 items or $10 \%$ of the whole col- 
lection. The OPAC is not yet accessible through the Internet.

In the central library there is an employee that holds a Ph. D. in Information Studies, but he is not the director. Four of the libraries employ TEI graduated librarians.

The University of Patra (U. Patra) was founded in 1964. There are Schools of Science, Engineering, Health Sciences, and Humanities. The university is located on a campus at Rio, a suburb of the city of Patras. There are almost 14,000 students. The library system consists of a central library and some small collections in departmental or sectional libraries. In total there are 14 full-time and 15 part-time (students for the most) employees working in the central library and the library's director holds a Ph.D in Philosophy. The library system has 14,000 volumes and 1500 serial titles. The director of the library selects materials for the reference collection. The library does not maintain a card catalog, but uses the integrated PLAS library system. It runs on a Novell LAN and has 15 PCs for the staff and for the users.

The library system follows the AACR2, DDC, but does not follow any particular subject headings.

The library offers 21 different networked CD-ROM databases. It has an active interlibrary loan department. It is very active and participates in different European Union (EU) projects as FastDoc, MECANO, etc.

Since 1985 the university has had a regional campus in Agrinio where a Department of Economics functions with 300 students. The library in Agrinio, with one employee, is autonomous and has 3,200 volumes and 90 serial titles. It follows AACR2, DDC, but no specific subject headings. Only an author card catalog is maintained. The regional library has no electronic connection with the library of the University of Patra.

The Democritus University of Thrace (D. U.Thrace) was founded in 1973 (Presidential Decree 374) in three different towns of Thrace. These are: Xanthi, Komotini, Alexandroupoli. Every school or department has a separate library even though the departments are in the same town. So there are three libraries in Komotini, two in Alexandroupoli, and one in Xanthi. There is no central administration and every library follows different standards and procedures. Each library has got a letter from the alphabet as a name, eg. A, B, C and so on, depending on when it was created. So the first library of the university was named Library A, the second Library B and so on. The libraries are not automated and are not electronically connected to each other. During 1977-1979 an attempt to automate Library B was not very successful (11).

Within the city of Xanthi there is the School of Engineering. It has 2,000 students. The library of this school has its own building with 45,000 items and 1,300 journals. It follows the DDC system. There is a backlog of books that are separated into fields of interest of the faculty members who have ordered the books.

In Komotini 4,000 students are studying in the School of Law (the oldest school of the university), the Physical Education Department, the Department of History and Ethnology. The new Department of Philology will accept students for the school year 1995-1996.

The Law Library (Library A) has got 75,000 items, 450 journals, and 80 newspapers. It applies its own developed thesaurus for subject headings.

The Physical Education library began operation in 1986. It holds 9,000 volumes, almost 300 journal titles and 200 video tapes. From 1992 it started to follow AACR2, and DDC.

The library of History and Ethnology Department has been in operation since 1991. It has got 6,500 volumes and 142 journal titles and follows the AACR2, DDC, and Sears subject headings. There is a program called LIBRARY that supports the library's automated procedures. Stacks are closed.

In Alexandroupoli there are the School of Medicine and the School of Education which has two departments (Primary, Kindergarten). The School of Medicine in Alexandroupoli was a regional campus of the Aristotle University of Thessaloniki until 1991. The library of medicine uses the classification system of NLM. It is a well organized small library with 1,500 volumes and 530 journals.

The two Education Departments have one common library. It uses AACR2 and DDC since 1991. It has about 1,600 volumes and 170 serial titles. It houses a special collection of "Archives of Thrace" and a collection of books that concerns the Thrace area and its history.

The University of Crete (U. Crete) is located in two towns, Herakleio and Rethymno. It was founded in 1973 but started to accept students in 1977. It is unique in that the librarian had full authority to 
organize the library. Therefore a central library was built instead of small dispersed libraries.

In Herakleio there are two campuses where 2,500 students are studying in the Schools of Medicine, and Sciences. The Schools of Social Sciences and Humanities with 2,000 students exist in Rethymno.

There is one administration for both libraries but they keep a degree of autonomy. They follow AACR2, LCSH and LC classification schemes. Both libraries use PTOLEMEOS II to automate their functions. The library in Herakleio converted all collection to MARC format. In Rethymno, $80 \%$ of the material has been converted (see Table 3). The two libraries are well organized and actively participate in E. U. projects (Heaven, Helen, etc) They are considered as a model for development and organization by other academic libraries.
In the University of Crete, the ILIS PTOLEMEOS I was developed in 1988. It was the first working ILIS made in Greece. In 1992, the redesigned and enhanced PTOLEMEOS II was released.

The School of Engineering of Crete (S. Eng. Crete) is located in Chania of Crete on one campus and it was founded in 1977. The school has four departments and 800 students. There is only one central library that holds 23,000 volumes and 600 journal titles. The director and the faculty are responsible for the collection management. The library has a mini computer, a LAN and uses PTOLEMAIOS II system for the automation. It has a map collection, audiovisual material, CD-ROMs, microfilms and microfishes.

The University of Aegeo (U.Aegeo) is dispersed among four islands of the Aegean Sea. In every is-

Table 3. ILIS, Automated cataloguing, retrospective cataloguing.

\begin{tabular}{|c|c|c|c|c|}
\hline Institution & ILIS & MARC & $\%$ converted & Retro \\
\hline \multicolumn{5}{|l|}{ N. K. U. Athens } \\
\hline Classic & $\operatorname{ABEKT}(*)$ & UNIMARC & $\mathrm{O}$ & - \\
\hline Byzantine & ABEKT $\left(^{*}\right)$ & UNIMARC & $\mathrm{O}$ & - \\
\hline Priv. Law & ABEKT & UNIMARC & $\mathrm{N} / \mathrm{A}$ & $\mathrm{N} / \mathrm{A}$ \\
\hline Trade Law & ABEKT & UNIMARC & $\mathrm{N} / \mathrm{A}$ & $\mathrm{N} / \mathrm{A}$ \\
\hline Phys. Ed. & ANALOGIO & UNIMARC & $\mathrm{N} / \mathrm{A}$ & $\mathrm{N} / \mathrm{A}$ \\
\hline Dentistry & ABEKT & UNIMARC & $\mathrm{N} / \mathrm{A}$ & $\mathrm{N} / \mathrm{A}$ \\
\hline H. S. Fine Arts & - & - & - & - \\
\hline N. Metsov. S. Eng & ALEF & UNIMARC & $\mathrm{O}$ & $\mathrm{N} / \mathrm{A}$ \\
\hline A. U. Econ \& Bus. & EQUILIBRIUM & UNIMARC & $\mathrm{N} / \mathrm{A}$ & $\mathrm{N} / \mathrm{A}$ \\
\hline Agr. U. Athens & CD/ISIS & UNIMARC & $\mathrm{N} / \mathrm{A}$ & $\mathrm{N} / \mathrm{A}$ \\
\hline \multicolumn{5}{|l|}{ A. U. Thes/niki: } \\
\hline Central Libr & ARIStotelis & & 8 & 1980 (**) \\
\hline Physics & PTOLEMEOS II & & 100 & Complete \\
\hline Panteio U. & GEAC & UNIMARC & 75 & $\mathrm{~N} / \mathrm{A}$ \\
\hline U. Pireas & PTOLEMEOS II & US-MARC & 100 & Complete \\
\hline U. Macedonia & P'TOLEMEOS II & US-MARC & 10 & Yes \\
\hline U. Ioannina & PLAS & UNIMARC & 10 & Yes \\
\hline $\begin{array}{l}\text { U. Patra } \\
\text { D. U. Thace. }\end{array}$ & PLAS & UNIMARC & & \\
\hline $\begin{array}{l}\text { D. Xanthi: } \\
\text { Xace: }\end{array}$ & - & - & - & - \\
\hline Komotini: & 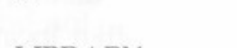 & 40 & & \\
\hline $\begin{array}{l}\text { Hist } \\
\text { Alexandroun: }\end{array}$ & LIBRARY & no-MARC & - & - \\
\hline \multirow{2}{*}{\multicolumn{5}{|c|}{$\begin{array}{l}\text { Medicine } \\
\text { U. Crete: }\end{array}$}} \\
\hline & $\begin{array}{l}\text { ADER } \\
\text { PTOLEMEOS II }\end{array}$ & & & \\
\hline Herakleion & & US-MARC & 100 & Complete \\
\hline Rethymnon & & US-MARC & 60 & Selected \\
\hline S. Eng. Crete & PTOLEMEOS II & US-MARC & N/A & $\mathrm{N} / \mathrm{A}$ \\
\hline U. Aegeo & GEAC & UNIMARC & 80 & Yes \\
\hline U. Ionio & PLAS(***) & UNIMARC & 0 & $\mathrm{~N} / \mathrm{A}$ \\
\hline U. Thessalia & GEAC & UNIMARC & 100 & - \\
\hline Charokopeios & - & - & - & - \\
\hline
\end{tabular}

${ }^{(*)}$ The departments will acquire ABEKT system. (**) The A.U. of Thessaloniki converted in MARC all the LS material hat was acquired since 1980 . (***) the system is on trial installation. 
land there is a library. On the island of Samos there is the Department of Mathematics that has been in operation since 1984. The department of Business Administration started on 1985 in the island of Chios. In Mytilini there are two departments: Social Anthropology, and Environmental Science. Finally on the island of Rhodes, there is the Department of Primary Education and the Department of Kindergarten Education. In total about 2,300 students are studying in the University of Aegeo.

The library in Mytilini works as a Central Library Service and it is responsible for the administration and the managing of the other three libraries. It holds 6,000 titles, and 250 journals. The library in Samos has 8,000 titles and 120 journals. The library in Chios 9,000 titles, and 150 serial titles. The library in Rhodes 2,000 titles.

All the libraries follow the same library standards: AACR2, DDC, and LCSH. All the subject headings assigned are only in English.

There is a mini computer system in Mytilini that runs the GEAC Advanced library system. The other libraries are connected to the library of Mytilini with leased lines. Their OPAC is accessible through the Internet.

The University of Ionio (U. Ionio) is located on the island of Kerkyra (Corfu) and was founded in 1984. It has a total of 1,000 students who study in four departments: History, Archives \& Biblionomy, Music, Foreign Languages - Translation \& Interpretation. Each department has its own library. The two libraries of History and Foreign Languages are more organized than the other two. All libraries combined hold 32,000 volumes and 600 serial titles. Each library processes its own material, but all use the same standards, AACR2, DDC, and LCSH.

The University of Thessalia (U.Thessalia) is located in the four towns of Thessalia region: Volos, Larisa, Trikala, and Karditsa. Founded in 1984, it has three engineering departments, medicine, production, education, and physical education. The library in Volos acts as a central library where the cataloguing of all library material is done. A database is built with all library records in UNIMARC format. The libraries are connected to the OPAC with leased lines. GEAC's Advance was chosen as the system to automate the functions of the libraries. The library in Volos has 20,000 volumes and a significant map collection. The library in Larisa has 8,000 volumes. All the libraries together have
300 serial titles. The Physical Education Department was founded in 1994 and it is in Trikala with about 30 students. In Karditsa about 30 students entered the Veterinary Department for first time in 1994. There are no libraries in Trikala and Karditsa at the moment.

The Charokopeios Higher School of Home Economy (12) (Charokopeios) opened in 1929 (Law 4360/9-7-1929) for first time as girls' teacher-training 3-years college of home economy. After many changes in the objectives, subjects and level of studies the school started to accept men students in 1984. The school has two departments, the Department of Household Economy and the Department of Dietology. The Department of Dietology has been in operation since 1984 and accepts 30 students per year. The school has one library with 4,000 volumes and five journals. Library materials are classified in general subjects. The library does not keep any card catalog.

\section{Collection development}

Collection development has the same pattern in all libraries: the faculty members have complete control over the material expenditures and decide what will be acquired. This happens even in universities where a central library exists. The peripheral libraries have their own budgets and steering committees. There are only some exceptions where the librarians get involved in the process of collection management. As a result, the collections reflect the individual research interests of the faculty and they are not representative of the body of knowledge.

There is a common library problem for all universities that have a health science school or a medicine school. Their collections are dispersed in hospitals, laboratories, clinics, and faculty offices that are often located in different or distant buildings. These locations cannot be considered libraries.

The duplication of material is a common phenomenon and has started to create financial problems, especially in serials. Recently the steering committee of the library system in Aristotle University of Thessaloniki decided to cut down the multiple serial titles subscriptions saving $40 \mathrm{mil}-$ lion drachmas (about 160,000 US.D) 


\section{Bibliographic organization}

It is generalized on the following four areas: the creation of catalogs, the application of cataloguing rules, the classification schemes and the subject headings used.

Almost all of the reviewed libraries offer some kind of catalog for bibliographic access. All libraries have open stacks with the exception of the central library of the Aristotle University of Thessaloniki and the University of Pireus.

All library systems use AACR2 with the ecxeption of the University of Ioannina and the National Metsovian School of Engineering. In the University of Ioannina some of the libraries follow the AACR2, but most of them do not use any rules at all.

All the reviewed libraries have some classification schemes. The majority of the library systems use DDC. The libraries of the National Kapodistrian University of Athens and those of the University of Ioannina have a variety of classification schemes (DDC, UDC, own - developed). Five peripheral libraries in the University of Ioannina do not classify their material. Some peripheral libraries in the Aristotle University of Thessaloniki apply home developed classification schemes. The LC is used in four library systems. One medicine library uses headings of the National Library of Medicine.

The LCSH is used in seven library systems out of the eighteen examined in this paper. One library system uses the Greek subject headings (Gr$\mathrm{SH})$ One peripheral library in the University of Ioannina uses SEARS. Three library systems have developed their own subject headings. There are three library systems that use subject headings only in English, three only in Greek, and two both English and Greek.

\section{Automation - automated cataloguing}

In the late 70 s most of the libraries did not consider automation as essential. Today there is a change in this attitude. Automation has become a serious and primary concern of all libraries. Librarians are aware that only with automation can the libraries be developed as modern organizations and stop being in isolation and decadence.

In the early ' 80 s some libraries started to develop in-house computer programs to automate their functions. These attempts were more or less unsuccessful. The reasons can be found in the lack of trained personnel and standards.
In the late ' 80 s the first working integrated library system PTOLEMEOS I was developed in the University of Crete. In early ' 90 s a redesigned and multi / cross- platform PTOLEMEOS II came out. In the University of Patras the PLAS system was developed at that time. At the same time the commercial developers came onto the scene of library automation in Greece.

The current situation appears in Table 3. Four library systems use the PTOLEMEOS II, and three GEAC Advance. PTOLEMEOS I is still functioning in the Physics departmental library of the Aristotle University of Thessaloniki. Recently the Aristotle University of Thessaloniki decided to acquire PTOLEMEOS II for its library system. At the moment there is no plan in the Kapodistrian University of Athens to buy an ILIS.

All academic libraries use some kind of cataloguing in MARC. The absence of a central decision making policy for all academic libraries has resulted in the application of different MARC formats in the libraries. The US-MARC is applied in six libraries, and the UNIMARC in fifteen.

Almost all academic libraries have, or plan to have, access to the Internet. This helps users and library staff to have access to information resources that are dispersed all over the world. The OPACs of the University of Crete and the University of Aegeo are accessible through Internet at this moment. More libraries will offer access to their OPACs via Internet in the future.

Some library systems have retro projects and some have already converted their collection to MARC format (see Table 3).

\section{Personnel}

The lack of specialized personnel in librarianship is still a big problem. TEI are the only institutions that educate librarians. The first TEI-librarians graduated in 1980. There is no school of librarianship at university level. There is only a related department of Archives and Biblionomy in the University of Ionio that accepted students for the first time during 1993-1994.

Another problem is the absence of library administrators with the proper education in librarianship, information technology and management. Ignorance is a major obstacle and ignorant administrators show resistance to change. 
A very common situation is that the supervisor of a peripheral or departmental library has a degree from that department with no library education or experience. In some the faculty intervene even in the bibliographic organization of the materials. As a result, the trained librarians have no responsibility over the library's administrative functioning.
According to a study that was conducted in 1990, a total of 139 employees were working in academic libraries. Two (1.4\%) employees hold a Ph.D, four (2.9\%) a MLS degree, 45 (32.4\%) hold a B.Sc, and $33(23.7 \%)$ TEI Library School degree (13).

Table 4 shows the current status of the personnel of the academic libraries in Greece. Three em-

Table 4. Educational background of the staff.

\begin{tabular}{|c|c|c|c|c|c|c|}
\hline Institution & Ph.D. & MLS & B.Sc. & TEI. L. S. & High School & \\
\hline \multicolumn{7}{|l|}{ N. K. U. Athens: } \\
\hline Classic & - & 1 & - & 3 & - & \\
\hline Byzantine & - & - & 1 & 2 & - & \\
\hline Priv. Law & - & - & - & 1 & - & \\
\hline Trade Law & - & - & - & 2 & - & \\
\hline Phys. Ed. & - & - & - & 3 & - & \\
\hline $\begin{array}{l}\text { Dentistry } \\
\text { H. S. Fine Arts }\end{array}$ & $\bar{N} / A$ & - & 1 & 2 & 2 & \\
\hline N. Metsov. S. Eng & - & - & 4 & 4 & 7 & \\
\hline A. U. Econ \& Bus. & - & - & 4 & 2 & 2 & \\
\hline \multirow{2}{*}{\multicolumn{6}{|c|}{ A.U. Thes/niki: }} & \\
\hline & & & & & 10 & \\
\hline $\begin{array}{l}\text { Central Libr } \\
\text { Perin-Reoion }\end{array}$ & $\overline{1}$ & $\begin{array}{l}1 \\
3\end{array}$ & $\begin{array}{r}5 \\
10\end{array}$ & 28 & $10\left(^{*}\right)$ & \\
\hline $\begin{array}{l}\text { Perip-Region } \\
\text { Panteio U. }\end{array}$ & $\begin{array}{l}1 \\
-\end{array}$ & $\begin{array}{l}3 \\
-\end{array}$ & 4 & 3 & 3 & \\
\hline $\begin{array}{l}\text { Panteio U. } \\
\text { U. Pireas }\end{array}$ & & - & 1 & 2 & 2 & \\
\hline U. Macedonia & - & - & 2 & 3 & 2 & \\
\hline U. Ioannina & 1 & - & 6 & 4 & 10 & \\
\hline $\begin{array}{l}\text { U. Patra } \\
\text { D. U. Thrace: }\end{array}$ & 1 & - & 4 & 2 & 5 & \\
\hline Xanthi & - & - & 3 & - & 2 & \\
\hline \multicolumn{7}{|l|}{ Komotini: } \\
\hline Law & - & - & 1 & 1 & 5 & \\
\hline Phys. Ed. & - & - & - & 1 & 1 & \\
\hline \multicolumn{4}{|l|}{ Alexandrou: } & & & \\
\hline Medicine & - & - & - & 1 & 1 & \\
\hline Educat. & - & - & - & 3 & 2 & \\
\hline \multicolumn{7}{|l|}{ U.Crete: } \\
\hline Herakleio & - & - & 4 & 5 & 3 & \\
\hline Rethymno & - & 1 & 9 & 1 & 4 & \\
\hline S. Eng. Crete & - & - & 1 & 3 & 1 & \\
\hline \multicolumn{7}{|l|}{ U. Aegeo: } \\
\hline $\begin{array}{l}\text { Samos } \\
\text { Chios }\end{array}$ & - & - & - & 2 & - & \\
\hline $\begin{array}{l}\text { Chios } \\
\text { Mitilini }\end{array}$ & - & - & 3 & $\begin{array}{l}1 \\
2\end{array}$ & i & \\
\hline $\begin{array}{l}\text { Mitilini } \\
\text { Rhodes }\end{array}$ & - & - & - & 1 & $\begin{array}{l}1 \\
-\end{array}$ & \\
\hline U. Ionio & - & - & 1 & 4 & 1 & \\
\hline U. Thessalia & - & - & 2 & 2 & 4 & \\
\hline Charokopeios & $\mathrm{N} / \mathrm{A}$ & $\mathrm{N} / \mathrm{A}$ & $\mathrm{N} / \mathrm{A}$ & N/A & N/A & \\
\hline $\begin{array}{l}\text { Total: } \\
\%\end{array}$ & $\begin{array}{r}3 \\
(1.2)\end{array}$ & $\begin{array}{r}6 \\
(2.4)\end{array}$ & $\begin{array}{r}67 \\
(26.1)\end{array}$ & $\begin{array}{r}102 \\
(39.8)\end{array}$ & $\begin{array}{r}78 \\
(30.5)\end{array}$ & $=\begin{array}{r}256 \\
(100)\end{array}$ \\
\hline
\end{tabular}

${ }^{*}$ ) Only for organized librairies.

Note 1. clerks, students and employees with a primary school education that are working in the academic librairies, are excluded from this study.

Note 2. Employees that hold a B.Sc. and a degree TEI school of library studies were put in TEI.L.S. column. 
ployees $(1.2 \%)$ hold a Ph. D. one of which is in Information Studies. Six employees $(2.4 \%)$ hold a Master in Library and Information Studies. One employee holds a Master in Computer Science. Totally $102(39.8 \%)$ TEI librarians are working in academic libraries.

The director of the library at the University of Pireas is the only one that holds a B.Sc. in Library Science. The director in the library of Physical Education in K. U. of Athens holds a B.Sc in Physical Education, a B.Sc. in Social Sciences and he has graduated from the TEI School of Librarianship.

It should be noticed that in the last five years there is an increase (about 16\%) in hiring TEI librarians. It seems that the TEI schools of librarianship give adequate knowledge to their students to face the challenges in the environment of the academic libraries. All libraries that hired TEI librarians have to show some kind of organization and development. It is obvious that the academic communities want to organize the libraries according to international practices.

\section{General assessments}

The creation of a library was the last concern in an academic institution. That is why there are no specially designed library buildings.

Smaller libraries and newly founded universities with small collections are fairly quick to use appropriate foundations to organize their libraries. This is more difficult for the older and bigger universities such as the National Kapodistrian University of Athens, the Aristotle University of Thessaloniki, the National Metsovian School of Engineering in Athens. These tend to be the most disorganized libraries.

In general all academic institutions in Greece were established in a similar pattern. There was no special interest in libraries, as the importance of the existence of a library was not recognized in an academic environment. The faculty, as well as the libraries, are responsible for the situation that has resulted in academic libraries. An endless loop was created: the faculty were not satisfied with the library's services; this led the faculty to ignore libraries; the ignored libraries did not develop; the underdeveloped libraries could not offer any services; and so on. This stereotype has started to change during recent years. This is evident when the libraries of mid- 80 s are compared to those of mid-90s.
Although new laws for higher education have been introduced, the legislation for the academic libraries is still the same (Law 1404/1983).

The academic libraries in Greece were static in the last decade. In this decade something started to move. Some libraries found the way to development and modernization. The rest will follow. It seems that each library can solve its own local problems. The next step is to find channels for communication and cooperation with other academic libraries in Greece and in the world.

Is the communication and the cooperation among the libraries going to be easy? It is neither easy but nor it is impossible. A pilot project for cooperation among academic libraries is running with 33 participating libraries for articles and dissertations delivery started with initiative of the National Documentation Center (EKT). Other areas of cooperation might be the shared cataloguing, and the development of a nationwide union catalog. How easily can libraries use a shared catalogue? The only standard that all the libraries follow seems to be the AACR2. The libraries will face new challenges with all these different MARC formats, classification schemes and subject headings when they try to share bibliographic records.

A problem that has to be solved is the transfer and the display of the Greek character set through a wide area network. At the moment only experts can display and send Greek characters through the Internet.

The academic libraries have lost precious time and the only way they can catch up is to keep in touch with the development of the libraries and information technology.

\section{Appendix}

\section{Integrated Library Information Systems}

ABEKT was developed in National Documentation Center (EKT) of Greece. At the moment it supports cataloguing, the online catalog and circulation. The acquisition and serial's check-in modules are under development. It is freely distributed. It is written in PASCAL and runs on IBM PC or PC compatibles.

ALEF is an integrated library system originated from Israel.

ANALOGIO is an integrated library information system developed by COMSYS Ltd. 
ARIStotelis supports only three modules: cataloguing, public access catalog, and bilingual authority files. It was developed in central library of Aristotle University of Thessaloniki by Paschalis Raptis to train the staff in machine readable cataloguing, and to build a MARC bibliographic database. ARIStotelis is writen totally in C language and runs under VMS, Unix, and Novell.

EQUILIBRIUM is a library system developed by Computer Academy Ltd. It uses INFORMIX DBMS and runs on Unix machines.

GEAC Advance is a world-wide known library system.

LIBRARY v.3.0 is based on dBASE III Plus and supports all library functions.

Micro CDS/ISIS is a library program that was developed by UNESCO and is freely distributed. It runs on PCs (IBM compatibles) and offers two modules: cataloguing and catalog.

PLAS system was developed in the University of Patras, uses ORACLE database, and supports all library functions. It runs under Novell local area network, Unix, and Xenix.

PTOLEMEOS I is the first integrated library system that was developed in the University of Crete. It runs under IBM's VM/CMS and is based on SQL/DS database. This system is not supported any more.

PTOLEMEOS II is an integrated library system that was originally developed at the University of Crete. It is based on INGRESS database and runs on platforms such as Unix, and VMS. It is sponsored by the Foundation for Research and Technology (ITE) of Crete, an institution that is affiliated with the University of Crete.

\section{References}

1. Krikelas James. "Academic Libraries in Greece". International Library Review 16: 1984; 235-246.

2. Birk Nancy and Karageorgiou Dimitris. "Academic Libraries in Greece: A New Profile". Libri 38: 2 1988; 81-93

3. Zachos Georgios and Papaioannou Takis. Ellinikes Panepistimiakes bibliothikes. Ioannina: University of Ioannina, 1991.

4. Keller Dean (ed.) Academic Libraries in Greece: the recent situation and future prospectus. New York, 1992.

5. The first Greek academic institution was the Ionios Academy that was founded in 1824. It stopped functioning in 1864. Source: Eleytherotypia newpaper, March 16, 1995.

6. Aristotle University in Thessaloniki, Aristotle University in Serres, Democritus University of Thrace in Komotini University of Thessalia in Trikala.

7. Law $184 / 79$ was modified by Law $562 / 80$.

8. The Annals of Higher School of Fine Arts for the year 1992-1993 and the report of Zachos and Papaioannou was used to find data for the Higher School of Fine Arts.

9. A sample of 90,000 items corresponded in $60,000 \mathrm{ti}$ tles.

10. Greek Subject Headings is the Greek version of LCSH. Libraries sometimes translate and adopt differently the subjects.

11. Papadoperakis Pericles. "The Automation project at Library B of Thrace University". Program 16, 1982; April: 57-66.

12. The report of Zachos and Papaioannou and the Annals of 1991 of the school have been used as source of data for Charokopeios Higher School of Home Economy.

13. Moreleli-Cacouris Mersini. "Library Education in Greece". In Academic Libraries in Greece: the present situation and future prospectus. New York, 1992; pp. 39-54. 
This document was created with Win2PDF available at http://www.win2pdf.com.

The unregistered version of Win2PDF is for evaluation or non-commercial use only. 